\title{
Work Stress and Marital Conflict as Correlate of Well-Being of Formal Caregivers in Abeokuta Township
}

\author{
Oyeleke Ajiboye Isaac (PhD)
}

Department of Sociology (Social Work Unit), University of Lagos, Akoka -Yaba, Lagos State, Nigeria

\begin{abstract}
This paper sought to investigate the mitigating offect of work stress and marital conflict on the psychological well-being of formal caregivers. The study took place in Abeokuta township of Ogun state Nigeria. Two hundred and seventeen (217) formal caregivers were purposively selected from five non- governmental social services agencies to take part in the study. Structured questionnaires were used for the purpose of data collection. Results reveals that job stress and work family conflict influenced psychological well-being of informal caregivers negatively. As a result of these findings, it was recommended that there should be reduction in the work load for institutional caregivers in order to reduce their stress level. More also good job rotation and schedule of work that do not conflict with family responsibilities should be put in place in order to enhance psychological well-being.
\end{abstract}

Keywords: Work stress, Work family conflict and Well-being.

\section{INTRODUCTION}

Formal caregivers give assistance to other people who as a result of physical challenges, chronic illness or cognitive impairment could not perform certain activities on their own; the word "care" implies intimacy and connection. Care giving most often involves "semi-care", the emotional works of managing feelings and establishing and maintaining relationships or what Bernard (1971) termed as the stroking function in addition to physical care. Home care involves the mixture of formal and informal care. The trend is towards emphasis on more formal care since, unlike the past, more informal caregivers are employed; they preffered to remain employed but must juggle limited time between care giving and maintaining a sick relative and a job.

The demands of striking balance between work and family life can be a major source of stress in an individual's life, leading to a harmful effects on one's health and wellbeing (Frone, 2003). Everyone experience stress in life on daily basis, however, excessive amounts of stress have the capacity to cause diminished performance in life including home, work life and relationships as well as the physical and psychological well-being of the individual (Casey, 2011). For many two aspects of life are two important and they are; work and family. As many people take up multiple jobs in order to have dual income and an increase in the number of hours spent at work, many find that they are now juggling between the dual roles of work and family responsibilities (Byron, 2005). This has led to the phenomena of conflict between work role and family responsibility which has generated increased interest in the research surrounding this topic (Karimi, Karimi, \&Nouri, 2011).

Work stress is majorly attributed to conflict within one's work role, work role ambiguity, and job role overload (Kahn \& Byosiere, 1992) and this in turn leads to role pressure and incompatibility (Greenhaus \& Beutell, 1985). Conversely, family-related stress for example, marital and parental conflict can interfere with work roles (Byron, 2005). Burdensome nature of care giving will often result in the caregiver suffering from severe depression, stress and social isolation.

Giving care to a recipient, can be very burdensome and demanding; it be a 24 hours, 7 days a week commitment which can take all of the caregiver's free time (Thomas Day, 2012). Singles, married, widowed adults or institutional care givers with extended families were more vulnerable to be victims of the problems in care giving. One of the concequence of this vulnerabikity is the insufficient fund to manage themselves and families. Single mothers or even married women that are bread winners of the family and still providing formal care services will be grossly unprepared to meet both personal needs and the developmental needs of their children. 


\section{STATEMENT OF THE PROBLEM}

Perhaps now more than ever before, job stress poses a serios health challenge threat to workers. Around half of all formal caregivers are effectively excluded from other paid jobs as a result of heavy demands and care responsibilities of loved ones. Formal caregivers lack time to care for themselves and their loved ones, they are likely to have problem in obtaining child care and other parenting issues and finally, stress related illness caused in the bid to of trying to balance work and family life schedules and priorities. Furthermore, individuals who experienced work-family conflict have been found to develop increased health risks, inapropiate performance in family roles (marital partner and parent), reduced family and life satisfaction, and poor marital relations. (Suchet \& Barling, 1986; Bedian, Burke, \& Moffett, 1988; Burke, 1988; Higgins, Duxbury, \& Irving, 1992; Hughes \&Galinsky, 1994; Boles, Johnston, \& Hair, 1997). Therefore, this study set out to ascertain the effect of work stress and marital conflict on the psychological health of formal caregivers.

\section{LITERATURE REVIEW}

\section{Karasek's Job Demand-Control Model}

This is a theory of work proposed by Karasek (1979) and expanded by Karasek and Theorell (1990). Karasek first proposition is referred to as the Job Demands-Control (JDC) Model, and also used the term "discretion" as a synonym for control. He suggested that excessive job demands or pressures (both psychological and psychosocial) can influence stress levels (especially psychological strain), on their own yet these stresses are not the most significant contributors to strain experiences. Rather, the level of strain people experience in their work will be determined by if they or do not have any control over the demands they have to deal with. This, according to Karasek (1979), means that there is a relationship between interactive effects of Demands and Control (or discretion) on stress levels.

Job stress may result into negative psychological well-being, such as depression, when the worker is do not know how he or she may control or or cope with high level of stress. Ability to control stess is benefitial to individuals' well-being as it encourages problem solving and allows for environmental changes that allows for effective coping mechanism with job demand (Ross \&Mirowsky, 1989). Thus control is argued to be one possible coping strategy that workers may use to improve their well-being.

\section{Work Stress and Psychological Well-Being}

Work stress comes in different forms and affects human being in different ways. To a small extent, stress can be positive but when stress becomes overwhelming, it can destroy the health, mood, productivity, relationships, and quality of life.

Copper model has also stressed the importance conflict between work and home as one of the sources of stressor. Although argument exits as to the specific definition of stress, researchers generally argued that stress is "an unpleasant emotional experience associated with fear, dread, anxiety, irritation, annoyance, anger, sadness, grief, and depression" (Motowidlo, Packard, \& Manning, 1986).

Smith, Larson, and Segal, (2007), argued thay, high level of stress can be disastrous and threaten the professionals' physical and mental health, and place them at risk for serious health-related problems over time. However, while some workplace stress is positive, too much stress can interfere with one's productivity and impact one's physical and emotional health, and ability to deal with it can mean the difference between success or failure.

Welbourne, Johnson, and Erez (1998) proposed that individuals in organizations enact two key work roles: the individual role and the caregiver's role. The job-holder role is representative of the formally prescribed (or in-role) duties and responsibilities that employees must fulfil, in contrast, the caregivers' duties includes employee hopes to be good organizational citizens. This demonstrated the empirical differences of these two conflicting roles, and recent research has demonstrated that employees often have feeling of pressure to engage in both types of roles (Perlow, 1998). Bedeian, (1988) found support for the relationship between work-family conflict and job stress. Other researchers have also reported a significant positive relationship between work-family conflict and work-stress. In an attempt to establish the relationship between work-family conflict and work-stress, Allen, (2000) did a meta-analysis examining the effects of work-family conflict and concluded that work-family conflict was significantly related to job/work stress, affective professional stress, and negative feelings at work. 


\section{Work-Family Conflict and Psychological Health}

Work-family conflict is a specific type of role conflict in which work-role demands interfere with family-role demands (Greenhaus \& Beutell, 1985). When conflict occurs it will gives adverse effects to both organization and individuals. The inability to endure both commitments will also form the behaviour of absenteeism, increasing the intent to turnover in work place including reducing the job commitment. Studies have long showed that these two variables are related, and have since found that this relationship has existed in the form of conflict.

Kahn et al. (1964) suggested that work-family conflict happens as a result of incompatibility between demands from work and family. Greenhaus and Beutell (1985) later summarized that job-family conflict happens when demands from one role affects one's ability to meet the demands associated with another role in another domain.

Greenhaus and Beutell (1985) and Kahn et al., (1964) examined job-family conflict as a onedimensional construct despite the fact that the definitions they provided demonstrated that job roles affected family roles and family affected work roles which suggests a bidirectional relationship (Allen, Hesrt, Bruck, \& Sutton, 2000; Frone, Russell, \& Cooper, 1992). Some other studies, however, did not recognize this aspect of the construct and treated job-family conflict as being comprised of two different but related forms of inter-role conflict focusing on how the two variables not interferes with each other. Family (Frone et al., 1992; Netemeyer, Boles \& McMurrian, 1996).

\section{HYPOTHESIS}

1. There is a significant relationship between work stress of formal caregivers and their psychological well-being.

2. There is a significant relationship between work family conflict of formal caregivers and their psychological well-being.

\section{METHODOLOGY}

\section{Research Design}

The research design that was used for this article paper is the Ex-post-facto design. The research design was adopted because the researcher did not manipulate any variable in the study. The variables of interest had already occurred to participants before the study began.

\section{Sample and Sampling Technique}

The study took place in Abeokuta township using five of the non-governmental agencies. The researcher employed the use of multi stage sampling technique. The initial stage was the use of purposive sampling technique in selecting participants and the second stage was the random sampling technique of selecting 217 formal caregivers who took part in the study.

\section{Research Instrument}

The instrument adopted for this study is a questionnaire by the researcher. Its aim is to know the effects of psychosocial factors on psychological well being of formal caregivers. Section A deals with the socio-demographic information of formal caregivers. Psychological well-being questionnaire developed by Ryff has sixteen items and respondents' perception on each stated items was rated using 5-point Likert scale ranging from strongly disagree to strongly agree. Work-family conflict scale was developed by Higgins and Duxbury (1992), it consists of 17 items of questions with 5-points Likert rating scale ranging from $1=$ never to $5=$ always. This measures the perception of the degree to which work interferes with family life of formal caregivers. Job stress Scale developed by Marlin Company and American Institute of Stress (1998). It consists of 8 items. The response format of the stress is a five-point rating scale ranging from $1=$ never to $5=$ very often. The author reported a reliability coefficient of this scale which are reasonably high (Cronbach's alpha. 0.87 ; retest reliability $\mathrm{r} 0.88$ ). The mean was used to dichotomize work overload into high and low work load.

\section{Research Procedure}

The researcher spent some days distributing the questionnaires to various agencies at different places in Abeokuta Town. The researcher was with the respondents to put them through the questions that may appear to be unclear to them. However, the questionnaires were collected back as soon as the respondents were through filling them. 
Oyeleke Ajiboye Isaac "Stress and Marital Conflict as Correlate of Well-Being of Formal Caregivers in Abeokuta Township"

\section{RESULTS}

Demographic Characteristics of the Respondents

Table5.1. Distribution of Respondents by Age

\begin{tabular}{|l|l|l|}
\hline Age & & \\
\hline $24-30$ years & 94 & 43.3 \\
\hline $31-35$ years & 73 & 33.6 \\
\hline 36 years and above & 50 & 23.0 \\
\hline
\end{tabular}

Table 5.1 above shows that $94(43.3 \%)$ of the respondents fall between the age group of 24-30 years while larger proportion $73(33.6 \%)$ were between the age bracket of 31-35 years and 50(23\%) fall between the age range of 36 years and above.

Table5.2. Distribution of respondents by sex

\begin{tabular}{|l|l|l|}
\hline Sex & Frequency & Percentage \\
\hline Male & 41 & 18.9 \\
\hline Female & 176 & 81.1 \\
\hline
\end{tabular}

Table 5.2 shows that $41(18.9 \%)$ of the 217 respondents were male while $176(81.1 \%)$ were female.

Table5.3. Distribution of respondents by marital status

\begin{tabular}{|l|l|l|}
\hline Marital status & Frequency & Percentage \\
\hline Married & 74 & 34.1 \\
\hline Single & 143 & 65.9 \\
\hline
\end{tabular}

Table 5.3 shows the marital status of the respondents, 35(16.1\%) were married, 56(25.8\%) were single, $39(18 \%)$ were separated/divorced and $87(40.1 \%)$ were single parents.

Table5.4. Distribution of respondents by educational status

\begin{tabular}{|l|l|l|}
\hline Educational status & Frequency & Percentage \\
\hline WASC/NECO & 13 & 6.0 \\
\hline NCE/OND & 6 & 2.8 \\
\hline Hnd/B.sc & 143 & 65.9 \\
\hline Postgraduate & 55 & 25.3 \\
\hline
\end{tabular}

Table 5.4 shows the educational status of the respondents, $13(6 \%)$ were O'level holder while $6(2.8 \%)$ possess NCE/OND certificate, larger proportion 143(65.9\%) acquired degree certificate and $55(25.3 \%)$ attained postgraduate level.

Table5.5. Distribution of respondents by personal income per month

\begin{tabular}{|l|l|l|}
\hline Personal income per month & Frequency & Percentage \\
\hline More than 100000 & 26 & 12.0 \\
\hline $100000-50000$ & 77 & 35.5 \\
\hline $49999-30000$ & 83 & 38.2 \\
\hline $29999-10000$ & 31 & 14.3 \\
\hline
\end{tabular}

Table 5.5 shows the personal income of the respondents per month 26(12\%) earned more than 100000 Naira per month, 77(35.2\%) earned between 100000-50000 Naira per month, majority $83(38.2 \%)$ reported receiving between 49999-30000 Naira monthly and 31(14.3\%) earned between 29999-10000 Naira per month.

\section{TEST OF HYPOTHESES}

\section{Hypothesis One}

Hypothesis one states that there is a significant relationship between job stress of formal caregivers and their psychological well-being. The hypothesis was tested using Pearson $r$ correlation analysis. The result is presented in table 5.6

Table5.6. Pearson Product Moment correlation showing the relationship between job stress of formal caregivers and psychological well-being

\begin{tabular}{|l|l|l|l|l|l|l|}
\hline Variables & Mean & S.D & N & r - cal & P & Remark \\
\hline Job stress of formal caregivers & 18.55 & 1.88 & 217 & & \multirow{2}{*}{ S.05 } & \multirow{2}{*}{ Sig. } \\
\hline Psychological well-being & 56.81 & 5.29 & 217 & -.62 & & \\
\hline
\end{tabular}


The results obtained from the test are shown in table 5.6 above. The table shows that there was significant inverse relationship between job stress of formal caregivers and psychological well-being $(\mathrm{r}=-.62, \mathrm{df}=217, \mathrm{p}<.05)$. This suggests that increase in job stress significantly relate to decrease in psychological well-being of formal caregivers.

\section{Hypothesis Two}

Hypothesis two states that there will be significant inverse relationship between work family conflict of formal caregivers and their psychological well-being. The hypothesis was tested using Pearson $r$ correlation analysis. The result is presented in table 5.7.

Table5.7. Pearson Product Moment correlation showing the relationship between work-family conflict of formal caregivers and psychological well-being

\begin{tabular}{|l|l|l|l|l|l|l|}
\hline Variables & Mean & S.D & N & r & P & Remark \\
\hline Work family conflict of formal caregivers & 12.52 & 1.88 & 217 & & \multirow{2}{*}{$<.05$} & \multirow{2}{*}{ Sig. } \\
\hline Psychological well-being & 56.81 & 5.29 & 217 & -.55 & & \\
\hline
\end{tabular}

The results obtained from the test are shown in table 5.7 above. The table shows that there was significant inverse relationship between work-family conflict of formal caregivers and psychological well-being ( $\mathrm{r}=-.551, \mathrm{df}=217, \mathrm{p}<.05)$. This suggests that increase in work family conflict of formal caregivers significantly leads to decreasing psychological well-being.

\section{DISCUSSION}

The paper looked into the influence of work stress and job- family conflict on the psychological health of institutional caregivers in Abeokuta town. The results of the tested hyphoteses are discussed below.

The result reveals that there was association between job- stress of institutional caregivers and their psychological health. This finding confirms the work of (Westman\&Etzion, 2006: Voydanoff, 2007). Job demands and work stresses have been established to have direct impacts on the quality of life of families and the psychological health of family members. Theories have proved that caregiving is an unwanted stressor that has consequences and usually negative for the caregiver's wellbeing. There was an association between job- family conflict of institutional caregivers and their psychological well-being. This indicates that as job- family conflict of institutional caregivers increases, psychological wellbeing decreases. This is also supported by the previous literature who reported that job and family conflict concerns among caregivers account for negative well-being of institutional caregivers as they conflict work and family role in a daily bases (Stone et al, 1987; Scharlach\& Boyd, 1989). Jobs connected with these negative outcomes are those with irregular work arrangement (Davis, Goodman, Pirretti, \& Almeida, 2008), rotating and off scheduled shift work (He, Zhao, \&Archbold, 2002), work schedules that conflict with marital partners (White\&Keith, 1990), excessively long work weeks (Voydanoff, 2005b), and jobs that separate family members for a long period of time require long periods of time (Orthner\& Rose, 2003; Zvonkovic, Solomon, Humble, \&Manoogian, 2005). These work schedules have demonstrated to have negative impact on family members especially those that involve off and on which can create role confusion in both the separating family member and members of their household.

\section{CONCLUSION}

Conclusions drawn in this study were premised on the tested hypotheses. Formal Caregiver perception of work stress and job-family conflict influenced formal caregivers' psychological wellbeing. Institutional caregivers with high level of stress will have negative psychological well-being. Formal caregivers with role conflict will also have negative psychological well-being. The above needs suggest that social workers and psychologists must provide caregivers with essential support and facilitations so as to reduce their poor psychological wellbeing. Being a formal caregiver would at the same time influence the caregivers' health and work status.

\section{RECOMMENDATIONS}

Participation of institutional caregivers in the society will be effective if adequately informed about career condition and appropriately educated by social workers, so as provide effective psychological support. Caregivers who experience high burden are at risk of developing emotional problem like 
depression. Individual with low socio-economic status may need Medicaid health. This includes assistance in in-home care and personal care, such as help with bathing, dressing, cooking, cleaning, eating, moving around, and a activities daily routine of life.

The current study suggests the following policies to support formal caregivers' efforts:

$>$ Reduction in work load of formal caregiver that could cause stress and other psychological health issues by employing more formal caregivers.

$>$ Good job rotation and scheduled of work for formal caregivers in order not to impaire with family responsibilities thereby reducing poor psychological wellbeing.

\section{REFERENCES}

[1] Allen T. Herst D, Bruck C, Sutton M. (2000). Consequences associated with work-to-family conflict: A review and agenda for future research. J Occup Health Psychol.; 5:278-308. doi: 10.1037/1076-8998.5.2.278.

[2] Allen, T. D. (2000). Consequences associated with work-to-family conflict: A review and agenda for future research. Journal of Occupational Health Psychology, 5(2), 278-30

[3] Bedeian, A. G. (1988). Outcomes of work-family conflict among married male and female professionals. Journal of Management, 14, 475 491

[4] Bernard, J. (1971). The paradox of a happy marriage. In V. Gornick \& B. Moran (Eds.), Women in sexist society (pp. 145-162). New York: Basic Books

[5] Biegel, D.E., Sales, E., Schulz, R. (1991). Family caregiving in chronic illness. Newbury Park, CA: Sage

[6] Boles, J. S. Johnston, M. W., \& Hair Jr., J.F. (1997). Role stress, work-family conflict and emotional exhaustion: Inter-relationships and the effects on some work-related consequences. Journal of Personal Selling and Sales Management, 17, 17-29

[7] Burke, R. J. (1988). Stressful events, work-family conflict, coping, psychological burnout, and well-being among police officers. Psychological Reports, 75, 787-800.

[8] Byron, K. (2005). A meta-analytic review of work-family conflict and its antecedents. Journal of Vocational Behavior, 67(2), 169-198.

[9] Casey, L. (2011). Stress and wellbeing in Australia in 2011: A state of the nation survey. Melbourne: Australian Psychological Society.

[10] Davis, K. D., Goodman, W. B., Pirretti, A. E., \&Almeida, D. M. (2008). Nonstandard work schedules, perceived family well-being, and daily stressors. Journal of Marriage and Family, 70,991-1003.

[11] Frone, M., Russell, M., \& Barnes, G. (2003).Wrok-family balance. In J. Quick \& L. Tetrick (Eds.), Handbook of occupational psychology (pp. 143-162). Washington: American Psychological Association.

[12] Frone, M., Russell, M., \& Cooper, M. (1992). Antecedents and outcomes of work-family conflict: testing a model of the owrk-family interface. Journal of Applied Psychology, 77, 65-78.

[13] Ganster, D. C., \& Schaubroeck, J. (1991). Work stress and employee health. Journal of Management, 17, 235-271.

[14] George, L.K., \& Gwyther, L.P. (1986). Caregiver well-being: A multidimensional examination of family caregivers of demented adults. Gerontologist, 26, 253-259

[15] Greenhaus, J. H., \&Beutell, N. J. (1985).Sources of conflict between work and family roles. Academy of Management Review, 10, 76-88.

[16] He, N., Zhao, J., \& Archbold, C. A. (2002). Gender and police stress: The convergent and divergent impact of work environment, work-family conflict, and stress coping mechanisms of female and male police officers. Policing: An International Journal of Police Strategies and Management,25, 687-708

[17] Higgins, C. A., \& Duxbury, L. E. (1992). Work-family conflict: A comparison of dual-career and traditional career men. Journal of Organizational Behavior, 13,389-411.

[18] Hughes, D. L., \& Galinsky, E. (1994). Gender, job and family conditions, and psychological symptoms. Psychology of Women Quarterly, 18,251-270

[19] Kahn, R. L., \& Byosiere, P. (1992). Stress in organizations. In M. D. Dunnette \& L. M. Hough (Eds.), Handbook of industrial and organizational psychology (Vol. 3, pp. 571-650). Palo Alto, CA: Consulting Psychologists Press 
[20] Kahn, R. L., Wolfe, D. M., Quinn, R. P., Snock, J. D., \& Rosenthal, R. A. (1964).Organizational stress: Studies in role conflict and ambiguity. New York: Wiley.

[21] Karasek R, Theorell T. Healthy work: Stress, Productivity and the Reconstruction of Working Life. New York: Basic Books; 1990.

[22] Karasek, R. A. 1979. “Job Demands, Job Decision Latitude, and Mental Strain: Implications for Job Redesign.” Administrative Science Quarterly, 24, 285-308.

[23] Karimi, L., Karimi, H., \&Nouri, A. (2011). Predicting employees' well-being using work-family conflict and job strain models. Stress and Health, 27(2), 111-122.

[24] Lazarus RS, Folkman S: Stress, Appraisal, and Coping. New York, NY: Springer Publishing Co, 1984.

[25] Motowidlo, S.P., Packard, J.-S.\& Manning, M. (1986). Occupational stress: Its causes and consequences for job performance. Journal of Applied Psychology, 71, 618-629.

[26] Netemeyer, R. G., Boles, J. S., \&Mc Murrian, R. (1996). Development and validation of workfamily conflict and family-work conflict scales. Journal of Applied Psychology, 81(4), 400-410

[27] Orthner, D. K., \& Rose, J. F. (2003). Family Contributions to Work Commitment. Journal of Marriage and Family, 48 (3), 573-581

[28] Pearlin LI, Mullan JT, Semple SJ, et al.: Caregiving and the stress process: an overview of concepts and their measures. Gerontologist 30 (5): 583-94, 1990.

[29] Perlow, L.A. (1998). Boundary control: The social ordering of work and family time in a Hightech corporation." Administrative Science Quarterly 43, 328-357.

[30] ROSS, C. E., and J. MIROWSKY. 1989. "Explaining the Social Patterns of Depression: Control and Problem Solving - or Support and Talking?" Journal of Health and Social Behavior, 30, 206-219

[31] Scharlach. A,„\& Boyd. S. (1989). Caregiving and employment: Results of an employee survey. The Gerontologist,29, 382-387.

[32] Smith, L., Larson, S. Jacobson, J., \& Segal,, J. (2007). Dealing with the aftermath: A qualitative analysis of mental health social workers reactions after a client suicide. Social Work, 51(4), 329341.

[33] Stone, A. A., Bovbjerg, D. H., Neale, J. M., Napoli, A., Valdimarsdottir, H., \& Gwaltney, J. M., Jr. (1987). Development of common cold symptoms following experimental rhinovirus infection is related to prior stressful life events. Behavioral Medicine, 8, 115-120.

[34] Suchet, M. and Barling, J. (1986). 'Working mothers: Interrole conflict, spouse support and marital functioning'. Journal of Occupational Behaviour, 1, 167-178.

[35] Thomas, J. (2012). Impact of family-supportive work variables on work-family conflict and strain: A control perspective. Journal of Applied Psychology, 80(1), 6-15.

[36] Van der Doef G, Maes TM 1999. Reducing work-family conflict through different sources of social support.J Vocat Behav.; 69 (3):462-76.

[37] Voydanoff, P. (2005b). The differential salience of family and community demands and resources for family-to-work conflict and facilitation. Journal of Family and Economic Issues, 26, 395-417.

[38] Voydanoff, P. (2007). Toward a conceptualization of perceived work-family fit and balance: A demands and resources approach. Journal of Marriage and Family,67, 822-836.

[39] Welbourne, T. M., Johnson, D. E., \&Erez, A. (1998). The role-based performance scale: Validity analysis of a theory-based measure. Academy of Management Journal, 41, 540-555.

[40] Westman, M., \& Etzion, D. (2006).The crossover of work family conflict from one spouse to the other. Journal of Applied Social Psychology, 35, 1936-1957.

[41] White, L. \& Keith, B. (1990).The effect of shift work on the quality and stability of marital relations. Journal of Marriage and the Family, 52, $453-462$

[42] Zvonkovic, A. M., Solomon, C. R., Humble, A. M., \& Manoogian, M. (2005). Family work and relationships: Lessons from families of men whose jobs require travel. Family Relations, 54(3), 411-422. 